\title{
Impact of certain endophytic fungi as biocontrol agents against sesame wilt disease
}

\author{
Hegazy M. G. A. ${ }^{* a}$, El Shazly A. M. ${ }^{\text {b }}$, Mohamed A. A. ${ }^{a}$, Hassan M. H. A. ${ }^{\text {c }}$ \\ ${ }^{a}$ Agricultural Botany Department, Faculty of Agriculture, Al-Azhar University, 71524 Assiut, Egypt \\ ${ }^{b}$ Agricultural Botany Department, Faculty of Agriculture, Al-Azhar University, Cairo, Egypt \\ ${ }^{c}$ Plant Pathology Department, Faculty of Agriculture, Al-Azhar University, 71526 Assiut, Egypt
}

\begin{abstract}
This study was conducted to evaluate the ability of some endophytic fungi, as biocontrol agents against sesame wilt caused by Fusarium oxysporum f. sp. sesame. Eleven fungal species belong to genus Fusarium was isolated from different localities in Sohag and Assiut governorates. All isolated species proved to be pathogenic on Giza-32 sesame cultivar. Twelve endophytic fungi isolates were isolated from some parts of various plants. The endophytic fungi isolates were tested for antagonistic activity by the dual culture and culture filtrate techniques. All endophytic fungal isolates were showed antagonistic activity against the causal pathogen in vitro. The endophytic Aspergillus niger was more antagonistic than other tested isolates toward the causal pathogen followed by A. clavatus, Penicillium chrysogenum and P. crustosum. All the tested fungal culture filtrates (FCF) were significantly affected the growth of the causal pathogen. FCF of Aspergillus terreus isolate at $20 \%$ concentration displayed the greatest inhibitory action to the pathogen mycelia growth. Single application with endophytic fungi or combined with Trichoderma sp. were significantly deceased the disease severity (\%) and increased the plant growth parameters such as shoot length, shoot weight, root weight and number of pods.
\end{abstract}

Keywords: endophytic fungi, Fusarium oxysporum f. sp. sesame, antifungal activity, Aspergillus spp., Trichoderma spp.

*Corresponding author: Hegazy M. G. A.,

E-mail address: mohamedhegazy.5419@azhar.edu.eg 


\section{Introduction}

Sesame (Sesamum indicum L.) is one of the most important crops cultivated in tropical and subtropical areas of Asia, Africa, South and Central America. It has been adapted to grow in semi-arid regions (Al-Yemeni et al., 2000). Sesame oil is used as edible oil, in paints and soap industry and has great medicinal value. This crop suffers from many pest and diseases like other crops. Fusarium wilt (Fusarium oxysporum), charcoal rot (Macrophomina phaseolina), leaf spot (Alternaria sesami), powdery mildew and Phytophthora blight are the most common diseases (Kotle, 1985). Sesame wilt caused by Fusarium oxysporum f. sp. seseame (Zap.) Cast was seriously damaging disease on sesame crop in Egypt and other countries (Abdou et al., 2001; Ahmed Hoda, 2008). Bacon et al. (1977) defines endophytes as microbes that colonize living internal tissues of plants without causing any immediate or negative effects. Endophytes can be transmitted vertically as well as horizontally: vertical transmission occurs through seeds and vegetative propagation of the host and horizontal transmission occurs through spores, external to host tissues (Carroll, 1988). In the 1970's, endophytes considered to be neutral: that is, they were believed to neither cause any harm nor benefit the plant. However, in the course of time, many studies revealed that endophytes play an important role in host protection against predators and pathogens (Azevedo et al., 2000). Many reports have provided evidence that endophytes synthesize myriads of secondary metabolites, which are not directly involved in the metabolism of the microorganisms but play a role in the fitness and survival of the endophytes and their hosts (Schulz et al., 2002). Thus, endophytes can be an important source of bio-compounds for combating fungal pathogens which reducing crop losses, and improving agricultural productivity with reduced agricultural chemical pesticide inputs. The present work aims to evaluate the ability of some endophytic fungi as biocontrol agents against Fusarium oxysporum f. sp. seseame the causal pathogen of sesame wilt.

\section{Materials and methods}

\subsection{Isolation and identification of the causal pathogens}

Isolation of the causal pathogenic fungi was carried out on PDA medium by agar plate method. Fusarium spp. were isolated from the infected sesame plants and brought into pure culture following standard procedure of hyphal tip technique. $250 \mathrm{mg} / \mathrm{L}$. of Chloramphenicol (L-Chloramphenicol) added to the medium before sterilizing to prevent the bacterial growth. The developed fungi were purified using the hyphal tip and/or the single spore techniques. Stock cultures were maintained on PDA slants at $5^{\circ} \mathrm{C}$ in a refrigerator for subsequent studies. Fungal isolates were identified by using the morphological features of mycelia and spores as described by (John and Brett, 2006; Ismail et al., 2015) and confirmed by Botany and Microbiology Department, Faculty of Science, Al-Azhar University, Assiut, Egypt. 


\subsection{Isolation and identification of endophytic fungi}

Isolation of endophytic fungi was carried out by the modified method of Hallmann et al. (2007). The collected root and branch samples were washed with mild detergent and thoroughly with running tap water to remove the soil particles and adhered debris and then finally washed with sterile distilled water. The samples were subjected to surface sterilization with $70 \%$ ethanol for $1 \mathrm{~min}$. For further surface sterilization and to remove adhering microorganisms, the samples were immersed in $4 \%$ sodium hypochlorite for $3 \mathrm{~min}$. Finally, the samples were rinsed with sterile distilled water and blot dried on sterile filter paper. The samples were cut into 5-10 mm using a sterile scalpel and cultured in Petri dishes containing PDA medium supplemented with chloramphenicol, (250 $\mathrm{mg} / \mathrm{L}$ ) to suppress bacterial growth. Petri dishes were sealed with parafilm and incubated at $27 \pm 2^{\circ} \mathrm{C}$ for 15 days under dark condition and monitored every day. The purified endophytic fungal isolates were transferred separately to PDA slants. Finally, all the purified endophytic fungi were maintained at $4{ }^{\circ} \mathrm{C}$ till further used. Endophytic fungi isolates were identified at Assiut University Moubasher Mycological Center (AUMMC), Assiut, Egypt based on their macro-and microscopic characteristics according to Raper and Fennell (1965), Ellis (1971), Pitt (1979) and Domsch et al. (1980, 2007). Identified isolates of Aspergillus clavatus, Aspergillus fumigatus, A. niger, A. terreus and Trichoderma sp. obtained friendly from the stock culture of Botany and Microbiology Department, Faculty of Science Al-Azhar University, Assiut, Egypt.

\subsection{Pathogenicity tests}

The experiments were carried out at the experimental greenhouse of Plant Pathology Department, Faculty of Agriculture, Assiut University, Assiut, Egypt in 2017 growing season. Sesame seeds from Giza-32 cultivar were sterilized by $1 \%$ sodium hypochlorite for 3 minutes, then washed gently by sterilized distilled water then dried well. Pathogenicity of $F$. oxysporum isolates were tested under greenhouse conditions. Pottery pots $(25 \mathrm{~cm}$ in diameter) were filled with formalin disinfested soil. Inocula were prepared by growing the desired fungal isolates at $25^{\circ} \mathrm{C}$ for two weeks on autoclaved sand barley medium. The prepared inoculum was added to the potted soil at the rate of $3.0 \%$ weight, mixed thoroughly with the soil, watered and let for a week. Pathogen-free sterilized sand barley was mixed at the same rate with the potted soil to serve as control treatment. Pots were planted with apparently healthy surface sterilized sesame seeds of Giza-32 cultivar at the rate of four seeds per pot. Four replicated pots were used for each treatment. The disease severity index (DSI) was recorded after 60 days from planting date. The disease index scale (0-5) according to Abdel-Razik Sahar et al. (2012) was used to measure the disease severity $(\%)$ of Fusarium wilt, in which (0 indicated no visible symptoms; 1 , slight vein-clearing and chlorosis of the leaves; 2 , yellowing and wilting of lower leaves and extend to 
upper leaves; 3, brown (discoloration) of the vascular systems of tap rot and stem; 4 , necrotic streaks on the base spread toward the stem apex and 5, premature plant death. The following equation was used to calculate the percentage of disease severity index (DSI) for each tested isolate:

$$
\text { DSI } \%=\left(\Sigma \mathrm{d} / \mathrm{d}_{\max } \times \mathrm{n}\right) \times 100
$$

Where, (d) is disease rating of each plant, $\left(d_{\max }\right)$ is the maximum disease rating and $\mathrm{n}$ is the total number of plants examined in each replicate.

\subsection{Antagonistic activity of the isolated} endophytic fungi in vitro

\subsubsection{Using the dual-culture technique}

In dual culture technique, the antagonistic effect of endophytic fungi was examined against Fusarium oxysporum f. sp. sesame. Discs of each isolate (6-mm discs in diameter) of endophytic fungi (7-days old) and the same size of another agar disc containing tested fungi were placed opposite to each other and close to the periphery of $90 \mathrm{~mm}$ petri plates containing PDA medium. For control treatment, Fusarium oxysporum f. sp. sesame was placed in a similar manner on PDA Petri plates. All pairing was carried out in three replicates and incubated at $25^{\circ} \mathrm{C} \pm 2$ for 7 days. After incubation, the clear zone between the two colonies at the interaction point was measured. After the desired incubation time, the colonies growth of both the tested endophytic fungi and pathogen were examined and photographed.

\subsubsection{Effect of endophytic fungi culture} filtrate on pathogen radial growth

The efficacy of culture filtrates of endophytic fungi against $F$. oxysporum $\mathrm{f}$. sp. sesame was assessed. Culture filtrates of Aspergillus niger, A. terreus isolate No. (1), Aspergillus terreus isolate No. (2), Penicillium chrysogenum isolate No. (1) with five concentrations $(1,2,5,10$, $20 \%$ ) were poured in sterilized Petri dishes. After solidification of PDA, mycelia discs of the $F$. oxysporum f. sp. sesame (6 $\mathrm{mm}$ in diameter) obtained from actively growing colonies were placed in the center of the solidified agar plates. Sterilized distilled water was added to PDA instead of culture filtrate served as control. The Petri dishes were incubated at $25 \pm 2{ }^{\circ} \mathrm{C}$ for four days and later the percent of inhibition in the radial colony growth compared to the control and calculated. The percent inhibition of mycelia growth of the pathogens was calculated using following formula (Hassan, 1992):

$$
\text { Inhibition }(\%)=(D 1-D 2) / D 1 \times 100
$$

Where, $D_{1}=$ colony diameter in control plate and $\mathrm{D}_{2}=$ colony diameter in treated plate.

2.5 Effect of endophytic fungi only or combined with Trichoderma sp. on controlling sesame wilt under greenhouse conditions

This experiment was carried out in 2018 growing season. Sterilized pots $(25 \mathrm{~cm}$ in diameter) containing sterilized soil were 
infested by adding the inoculums of $F$. oxysporum f. sp. sesame grown on sand barley medium at the rate of $(2.0 \%$ weight), mixed thoroughly with the soil. After one-week, equal amounts of inocula of the antagonistic fungi only and/ or with Trichoderma sp. were separately added to each pot and thoroughly watered. Pots containing inoculum of $F$. oxysporum $\mathrm{f}$. sp. sesame only were used as control. Pots containing Trichoderma sp. only was used as positive control. Three replicates were used for each treatment and 5 sterilized sesame seeds Giza 32 cultivar were sown in each pot. Plants were irrigated when it needs and examined periodically. Percentages of disease severity index of sesame wilt were recorded as above mentioned. The plant growth parameter such as shoot length, shoot weight, root weight and number of pods were recorded.

\subsection{Statistical analysis}

Analyses of variance were carried out using COSTAT program and employed to Duncan's Multiple Range Test to compare the treatments means at $\mathrm{p} \leq 0.05$ (Gomez and Gomez, 1984).

\section{Results}

3.1 Isolation, identification and pathogenic capability of the causal pathogens isolates

Fifty-five samples were randomly collected from certain areas related to Sohag and Assiut governorates. These localities were, El Maragha, Al- Tolihat, Nazlet Ali (Sohag governorate), Bacor,
Sedfa (Assiut governorate), Egypt. Fungal species recovered from these previous areas are listed in Table (1). In general, data indicate that, eleven fungal species belong to genus Fusarium were: Fusarium camptoceras (two isolates), $F$. proliferatum (two isolates), Fusarium tricinctum, Fusarium oxysporum f. sp. sesame (two isolates), Fusarium dimerum (two isolates), Fusarium solani (two isolates), and Fusarium verticillioides. Data in Table (1) reveal that, Fusarium oxysporum f. sp. sesame caused the highest percentage of disease severity $(85$ $\%$ ). While Fusarium dimerum isolate No. (2) and Fusarium solani isolate No. (1) gave the same percent of disease severity $(72.5 \%)$. The percentage of disease severity for isolates Fusarium tricinctum isolate No. (1) and Fusarium camptoceras isolate No. (1) were $(66 \%$ and $65 \%)$ respectively. On the other hand, Fusarium camptoceras isolate No. (2), Fusarium dimerum isolate No. (1) and Fusarium verticillioides gave the lowest percentage of disease severity $(42.5 \%, 39 \%$ and 39 $\%$, respectively).

\subsection{Isolation and Identification of endophytic fungi}

Eight endophytic fungi isolates were isolated from some parts of various plants, i.e. Aspergillus sydowii isolated from Olive (Oleae uropaea). Two species of Penicillium crustosum isolate No. (1), $P$. crustosum isolate No. (2) and Alternaria alternata were isolated from Alhagi plant (Alhagi maurorum) (Sohag Al Tolihat). Aspergillus terreus isolate No. (2), Penicillium crustosum isolate No. (3) and Penicillium chrysogenum isolate 
No. (1) were isolated from Alhagi plant (Alhagi maurorum) collected from Sohag - Nazlet Ali. Also, Penicillium chrysogenum isolate No. (2) was isolated from Pomegranate (Punicam granatum). Finally, Aspergillus clavatus, Aspergillus fumigatus, Aspergillus sniger, Aspergillus terreus isolate No. (1) obtained from stock culture of Department of Botany and Microbiology, Faculty of Science, AlAzhar University, Assiut, Egypt (Table 2, 3).

Table (1): Isolation, identification localities and pathogenic capability of the causal pathogens.

\begin{tabular}{|c|c|c|}
\hline Fungal isolate & Locality & Disease severity (\%) \\
\hline Fusarium camptoceras $_{(1)}$ & El Maragha & $65^{\mathrm{bc}}$ \\
\hline Fusarium camptoceras $_{(2)}$ & Sedfa & $42.5^{\mathrm{e}}$ \\
\hline Fusarium proliferatum $_{(1)}$ & El Maragha & $51^{\text {cde }}$ \\
\hline Fusarium proliferatum $_{(2)}$ & El Maragha & $46^{\mathrm{de}}$ \\
\hline Fusarium tricinctum $_{(1)}$ & El Maragha & $66^{\mathrm{bc}}$ \\
\hline Fusarium oxysporum f. sp. sesame & Nazlet Ali & $85^{\mathrm{a}}$ \\
\hline Fusarium dimerum $_{(1)}$ & Bacor & $39^{\mathrm{e}}$ \\
\hline Fusarium dimerum $_{(2)}$ & Nazlet Ali & $72.5^{\mathrm{ab}}$ \\
\hline Fusarium solani $_{(1)}$ & Bacor & $72.5^{\mathrm{ab}}$ \\
\hline Fusarium solani $_{(2)}$ & Nazlet Ali & $64^{\text {bcd }}$ \\
\hline Fusarium verticillioides & Sedfa & $39^{\mathrm{e}}$ \\
\hline Control (uninfected plants) & & $00^{\mathrm{f}}$ \\
\hline
\end{tabular}

3.3 Antagonistic activity of the isolated endophytic fungi in vitro

\subsubsection{Using the dual-culture method}

The isolates of endophytic fungi were tested for antagonistic activity by the dual culture technique. A total of 12 endophytic fungal isolates were showed antagonistic activity against $F$. oxysporum f. sp. sesame. These endophytic fungi were: Alternaria alternate, Aspergillus clavatus, Aspergillus fumigatus, Aspergillus niger, Aspergillus sydowii, Aspergillus terreus isolate No. (1), Aspergillus terreus isolate No. (2), Penicillium chrysogenum isolate No. (1), Penicillium chrysogenum isolate No. (2),
Penicillium crustosum isolate No. (1), Penicillium crustosum isolate No. (2) and Penicillium crustosum isolate No. (3). Data in Table (4) indicated that the endophytic fungus Aspergillus niger was more active against Fusarium oxysporum f. sp. sesame with antagonistic activity $(11.6 \mathrm{~mm})$ followed by Aspergillus clavatus and Penicillium chrysogenum (1) $(9.2 \mathrm{~mm})$ and Penicillium crustosum (2). While, Aspergillus terreus (2) gave moderate antagonistic activity $(5.9 \mathrm{~mm})$ against the causal pathogen. On the other hand, Alternaria alternate, Aspergillus sydowii and Aspergillus fumigatus exhibited the lowest antagonistic activity against causal pathogen $(1.5 \mathrm{~mm}, 1.3 \mathrm{~mm}$ and $0.8 \mathrm{~mm}$ ), respectively. 
Table (2): List of endophytic fungi isolates which isolated from some parts of various plants.

\begin{tabular}{|c|c|c|c|}
\hline Isolates & Localities & Host & Source \\
\hline Aspergillus sydowii & Assiut & Olive (Oleae uropaea) & Branch \\
\hline Penicillium crustosum $_{(1)}$ & \multirow{3}{*}{$\begin{array}{l}\text { Sohag } \\
\text { Al- Tolihat }\end{array}$} & \multirow{3}{*}{ Alhagi (Alhagi maurorum) } & Root \\
\hline Penicillium crustosum $_{(2)}$ & & & Root \\
\hline Alternaria alternata & & & Root \\
\hline Aspergillus terreus $_{(2)}$ & \multirow{4}{*}{$\begin{array}{l}\text { Sohag } \\
\text { Nazlet Ali }\end{array}$} & \multirow{3}{*}{ Alhagi (Alhagi maurorum) } & Root \\
\hline${\text { Penicillium } \text { crustosum }_{(3)}}$ & & & Root \\
\hline Penicillium chrysogenum $_{(1)}$ & & & Root \\
\hline Penicillium chrysogenum $_{(2)}$ & & Pomegranate (Punicam granatum) & Branch \\
\hline
\end{tabular}

Table (3): Identification of endophytic fungi isolated from some parts of various plants.

\begin{tabular}{lcl}
\hline Isolate code & AUMMC No. & \multicolumn{1}{c}{ Identification } \\
\hline $\mathrm{AL}_{1}$ & 13894 & Penicillium crustosum Thom \\
\hline $\mathrm{AL}_{2}$ & 13895 & Penicillium crustosum Thom \\
\hline $\mathrm{AL}_{3}$ & 13896 & Alternaria alternate (Fries) Keissler \\
\hline $\mathrm{AL}_{6}$ & 13897 & Aspergillus terreus Thom \\
\hline $\mathrm{AL}_{7}$ & 13898 & Penicillium crustosum Thom \\
\hline $\mathrm{AL}_{8}$ & 13899 & Penicillium chrysogenum Thom \\
\hline $\mathrm{P}_{3}$ & 13900 & Penicillium chrysogenum Thom \\
\hline $\mathrm{O}_{3}$ & 13904 & Aspergillus sydowii (Bainier \& Sartory) Thom \& Church \\
\hline
\end{tabular}

(AL: Alhagi; P: Pomegranate; O: Olive).

\subsubsection{Effect of endophytic fungi culture} filtrate on the growth of the causal pathogens in vitro

\section{A laboratory experiment was carried out}

to determine the effect of fungal culture filtrates (FCF) of the endophytic fungi and evaluating their role as bioagent against the causal pathogen. The obtained results are listed in Table (5).

Table (4): Antagonistic activity of the isolated endophytic fungi against Fusarium oxysporum f. sp. sesame in dual culture.

\begin{tabular}{lll}
\hline Isolate No. & Endophytic fungi isolate & Average of inhibition zone diameter $(\mathrm{mm})$ \\
\hline 1 & Alternaria alternate & $1.5^{\text {ef }}$ \\
\hline 2 & Aspergillus clavatus & $9.2^{\mathrm{b}}$ \\
\hline 3 & Aspergillus fumigatus & $0.8^{\mathrm{ef}}$ \\
\hline 4 & Aspergillus niger $^{\mathrm{a}}$ & $11.6^{\mathrm{a}}$ \\
\hline 5 & Aspergillus sydowii $^{\mathrm{ef}}$ & $1.3^{\mathrm{e}}$ \\
\hline 6 & Aspergillus terreus $_{(1)}$ & $2.3^{\mathrm{e}}$ \\
\hline 8 & Aspergillus terreus $_{(2)}$ & $5.9^{\mathrm{cd}}$ \\
\hline 9 & Penicillium chrysogenum $_{(1)}$ & $9.2^{\mathrm{b}}$ \\
\hline 10 & Penicillium chrysogenum $_{(2)}$ & $2.3^{\mathrm{e}}$ \\
\hline 11 & Penicillium crustosum $_{(1)}$ & $7.1^{\mathrm{bc}}$ \\
\hline 12 & Penicillium crustosum $_{(2)}$ & $8.2^{\mathrm{b}}$ \\
\hline 13 & Penicillium crustosum $_{(3)}$ & $2.8^{\mathrm{e}}$ \\
\hline
\end{tabular}

Means followed by the same letters ( $\mathrm{s}$ ) in a column are not significantly different at $(\mathrm{p} \leq 0.05)$ according to Duncan's multiple-range test. 
Table (5): Effect of endophytic fungi culture filtrates on radial growth of $F$. oxysporum $\mathrm{f}$. sp. sesame the causal pathogen of sesame wilt.

\begin{tabular}{|c|c|c|c|}
\hline Endophytic fungi & $\begin{array}{c}\text { Concentration } \\
(\%)\end{array}$ & $\begin{array}{l}\text { Average of colony } \\
\text { diameter }(\mathrm{mm})\end{array}$ & $\begin{array}{c}\text { Inhibition } \\
(\%)\end{array}$ \\
\hline \multirow{5}{*}{ Aspergillus niger } & 1 & 73.30 & $18.55^{\mathrm{i}}$ \\
\hline & 2 & 69.30 & $23.00^{\text {ghi }}$ \\
\hline & 5 & 63.30 & $29.66^{\text {fgh }}$ \\
\hline & 10 & 57.00 & $36.66^{\text {ef }}$ \\
\hline & 20 & 45.00 & $50.00^{d}$ \\
\hline \multirow{5}{*}{ Aspergillus terreus $_{(1)}$} & 1 & 68.30 & $24.11^{\text {ghi }}$ \\
\hline & 2 & 55.00 & $38.88^{\mathrm{e}}$ \\
\hline & 5 & 45.00 & $50.00^{d}$ \\
\hline & 10 & 36.60 & $59.33^{\mathrm{bc}}$ \\
\hline & 20 & 26.60 & $70.44^{\mathrm{a}}$ \\
\hline \multirow{5}{*}{ Aspergillus terreus $_{(2)}$} & 1 & 73.30 & $18.55^{\mathrm{i}}$ \\
\hline & 2 & 65.30 & $27.44^{\text {gh }}$ \\
\hline & 5 & 56.60 & $37.11^{\text {ef }}$ \\
\hline & 10 & 43.30 & $51.88^{\mathrm{cd}}$ \\
\hline & 20 & 33.30 & $63.00^{\mathrm{ab}}$ \\
\hline \multirow{5}{*}{ Penicillium chrysogenum $_{(1)}$} & 1 & 75.00 & $16.66^{\mathrm{i}}$ \\
\hline & 2 & 70.00 & $22.22^{\mathrm{hi}}$ \\
\hline & 5 & 62.00 & $31.11^{\text {efg }}$ \\
\hline & 10 & 55.00 & $38.88^{\mathrm{e}}$ \\
\hline & 20 & 44.00 & $51.11^{\mathrm{cd}}$ \\
\hline Control & & 90.00 & $00.00^{j}$ \\
\hline
\end{tabular}

Means followed by the same letters ( $\mathrm{s})$ in a column are not significantly different at $(\mathrm{p} \leq 0.05)$ according to Duncan's multiple-range test.

Data in Table (5) showed that all the tested fungal culture filtrates were significantly affected the growth of the causal pathogen. FCF of Aspergillus terreus isolate No. (1) at $20 \%$ concentration and Aspergillus terreus isolate No. (2) at the same concentration displayed the greatest inhibitory action to the pathogen. While, Penicillium chrysogenum isolate No. (1), Aspergillus niger and Aspergillus terreus isolate No. (1) at $1 \%$ concentration exhibited the lowest inhibitory effect. Other tested concentration showed moderate inhibitory effect.

3.4 Effect of endophytic fungi in controlling sesame wilt and plant growth parameters under greenhouse conditions
Data in Table (6) indicated that application of endophytic fungi affected both disease severity and plant growth parameters. Endophytic fungi have significantly decreased the disease severity (\%) and increased the plant growth parameter such as shoot length, shoot weight, root weight and number of pods. Endophytic fungi can decrease the disease severity percentage. Aspergillus niger gave the lowest percentage of disease severity (36\%). Both A. terreus (1) and Penicillium chrysogenum (1) gave the same percentage of disease severity (41 \% and $38.6 \%$ respectively) without significant differences. While, Aspergillus terreus (2) gave moderate disease severity percentage $(52 \%)$. Concerning the plant growth parameter, Aspergillus terreus (2) 
gave the highest value. This treatment increased shoot length $(96 \mathrm{~cm})$, fresh shoot weight $(10.3 \mathrm{~g})$ and fresh root weight $(7.6 \mathrm{~g})$.

\subsection{Effect of Trichoderma sp. alone or} combined with endophytic fungi in controlling sesame wilt and plant growth parameters under greenhouse conditions

Data in Table (7) indicated that, Trichoderma sp. alone or combined with endophytic fungi isolates significantly affected both wilt severity percentage and increased the plant growth parameters. Trichoderma sp. as single treatment or combined treatment as A. niger +
Trichoderma sp. gave the lowest percentage of disease severity (13.3\% and $16 \%$ respectively). Moderate of disease severity obtained by A. terreus (1) + Trichoderma sp. (25.3\%) On the other side, A. terreus $_{(2)}+$ Trichoderma sp. as combined treatment gave the highest percentage of disease severity $(46.6 \%)$. In general, single treatment was better than combined treatments. Trichoderma sp. was the best treatment and it increased shoot height $(98 \mathrm{~cm})$, fresh shoot weight $(42.3 \mathrm{~g})$ and fresh root weight $(25.6 \mathrm{~g})$. While, combined treatment Trichoderma sp. + Penicillium chrysogenum (1) was the lowest treatment shoot height $(80 \mathrm{~cm})$, fresh shoot weight $(17.5 \mathrm{~g})$ and fresh root weight $(9.3 \mathrm{~g})$.

Table (6): Effect of endophytic fungi on sesame wilt severity and plant growth parameters under greenhouse conditions.

\begin{tabular}{|c|c|c|c|c|c|c|c|}
\hline \multirow[b]{3}{*}{ Treatments } & \multirow{3}{*}{$\begin{array}{c}\text { Disease } \\
\text { Severity } \\
(\%)\end{array}$} & \multicolumn{6}{|c|}{ Plant growth parameters } \\
\hline & & \multicolumn{3}{|c|}{ Shoot } & \multicolumn{2}{|c|}{ Root } & \multirow[b]{2}{*}{$\begin{array}{c}\text { Number } \\
\text { of bods }\end{array}$} \\
\hline & & $\begin{array}{l}\text { Plant } \\
\text { height } \\
(\mathrm{cm})\end{array}$ & $\begin{array}{l}\text { Fresh } \\
\text { weight } \\
(\mathrm{g})\end{array}$ & $\begin{array}{c}\text { Dry } \\
\text { weight }(\mathrm{g})\end{array}$ & $\begin{array}{c}\text { Fresh } \\
\text { weight } \\
(\mathrm{g})\end{array}$ & $\begin{array}{c}\text { Dry } \\
\text { weight (g) }\end{array}$ & \\
\hline Aspergillus niger & $36^{\mathrm{c}}$ & $73^{a b}$ & $11.8^{\mathrm{b}}$ & $3.66^{\mathrm{b}}$ & $3.33^{\mathrm{c}}$ & $1.3^{\mathrm{c}}$ & $10^{\mathrm{c}}$ \\
\hline Aspergillus terreus $_{(1)}$ & $41^{\mathrm{bc}}$ & $83^{\mathrm{b}}$ & $19^{\mathrm{a}}$ & $4.66^{\mathrm{a}}$ & $7.83^{a}$ & $3.43^{\mathrm{a}}$ & $16^{\mathrm{a}}$ \\
\hline Aspergillus terreus $_{(2)}$ & $52^{b}$ & $96^{\mathrm{a}}$ & $10.3^{\mathrm{bc}}$ & $3^{\mathrm{c}}$ & $7.6^{\mathrm{a}}$ & $2.66^{b}$ & $11^{\mathrm{b}}$ \\
\hline Penicillium chrysogenum $_{(1)}$ & $38.6^{\mathrm{bc}}$ & $85^{\mathrm{b}}$ & $10.6^{\mathrm{bc}}$ & $2.2^{\mathrm{d}}$ & $6.66^{\mathrm{ab}}$ & $1.46^{\mathrm{c}}$ & $10^{\mathrm{c}}$ \\
\hline Control (untreated) & $94.3^{\mathrm{a}}$ & $56^{\mathrm{c}}$ & $9.6^{\mathrm{c}}$ & $2^{\mathrm{c}}$ & $4^{b}$ & $1.16^{\mathrm{c}}$ & $9^{d}$ \\
\hline
\end{tabular}

Means followed by the same letters ( $s$ ) in a column are not significantly different at $(\mathrm{p} \leq 0.05)$ according to Duncan's multiple-range test.

Table (7): Effect of endophytic fungi and Trichoderma sp. in controlling sesame wilt and plant growth parameters in greenhouse.

\begin{tabular}{|c|c|c|c|c|c|c|c|}
\hline \multirow[b]{3}{*}{ Treatments } & \multirow{3}{*}{$\begin{array}{c}\text { Disease } \\
\text { Severity } \\
(\%)\end{array}$} & \multicolumn{6}{|c|}{ Growth parameters } \\
\hline & & \multicolumn{3}{|c|}{ Shoot } & \multicolumn{2}{|c|}{ Root } & \multirow[b]{2}{*}{$\begin{array}{l}\text { Number } \\
\text { of bods }\end{array}$} \\
\hline & & $\begin{array}{l}\text { Shoot } \\
\text { height } \\
(\mathrm{cm})\end{array}$ & $\begin{array}{c}\text { Fresh } \\
\text { weight } \\
(\mathrm{g})\end{array}$ & $\begin{array}{c}\text { Dry } \\
\text { weight } \\
(\mathrm{g})\end{array}$ & $\begin{array}{l}\text { Fresh } \\
\text { weight } \\
\text { (g) }\end{array}$ & $\begin{array}{c}\text { Dry } \\
\text { weight } \\
(\mathrm{g})\end{array}$ & \\
\hline A. niger + Trichoderma $\mathrm{sp}$. & $16^{\mathrm{c}}$ & $91.3^{b}$ & $24.6^{c}$ & $9.6^{\mathrm{b}}$ & $14.6^{\mathrm{b}}$ & $7.1^{\mathrm{b}}$ & $8^{\mathrm{c}}$ \\
\hline A. terreus $_{(1)}+$ Trichoderma $\mathrm{sp}$. & $25.3^{\mathrm{bc}}$ & $84^{\mathrm{c}}$ & $27^{\mathrm{b}}$ & $8.5^{\mathrm{c}}$ & $15.3^{\mathrm{b}}$ & $5.6^{\mathrm{c}}$ & $12^{\mathrm{b}}$ \\
\hline 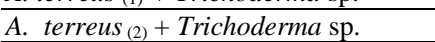 & $46.6^{\mathrm{a}}$ & $84^{\mathrm{c}}$ & $27.5^{b}$ & $7.6^{d}$ & $13 \mathrm{c}$ & $5.4^{\mathrm{c}}$ & $6^{d}$ \\
\hline P. chrysogenum $(1)+$ Trichoderma $\mathrm{sp}$. & $36^{\mathrm{ab}}$ & $80^{\mathrm{d}}$ & $17.5^{\mathrm{d}}$ & $6^{\mathrm{e}}$ & $9.3^{\mathrm{d}}$ & $3.5^{\mathrm{d}}$ & $13^{\mathrm{a}}$ \\
\hline Control (Trichoderma sp. only) & $13.3^{\mathrm{c}}$ & $98^{\mathrm{a}}$ & $42.3^{a}$ & $12.6^{\mathrm{a}}$ & $25.6^{\mathrm{a}}$ & $14.3^{\mathrm{a}}$ & $12^{\mathrm{b}}$ \\
\hline
\end{tabular}

Means followed by the same letters ( $\mathrm{s}$ ) in a column are not significantly different at $(\mathrm{p} \leq 0.05)$ according to Duncan's multiple-range test. 


\section{Discussion}

In Egypt, sesame (Sesamum indicum L.) is subject to be attacked by many soil borne pathogens. The most destructive diseases are Fusarium wilt caused by $F$. oxysporum f. sp. sesame at any growth stages and causing considerable losses of seed yield (Sahab et al., 2008; Elewa et al. (2011) and Ziedan et al. (2011). Similar results obtained by this study which revealed that, Fusarium oxysporum f. sp. sesame caused the highest percentage of disease severity. Eight endophytic fungi such as Aspergillus sydowii, Penicillium crustosum, Alternaria alternata. Aspergillus terreus and $P$. chrysogenum, were isolated from some parts of various plants. This result agreement with those obtained by Garoe et al. (2012). Aspergillus niger gave the highest activity against Fusarium oxysporum f. sp. sesame followed by Aspergillus clavatus and Penicillium chrysogenum. These results in agreement with those obtained by Kim et al. (2007), Rukachaisirikul et al., (2007) and Ge et al. (2008) who reported that, endophytic fungi isolated from vegetable plants showed in vitro antagonism against Pythium ultimum, $P$. infestans and $P$. capsici. All the tested fungal culture filtrates (FCF) were significantly affected the growth of the causal pathogen. FCF of Aspergillus terreus isolate at $20 \%$ concentration displayed the greatest inhibitory action to the pathogen mycelial growth. These results in a harmony with those obtained by several investigators (Nair and Padmavathy, 2014; Vidal and Jaber, 2015). They reported that some endophytic fungi can produce compounds that have growth-inhibitory activities toward herbivores and phytopathogens and thus can be used as biological control agents. Single application with endophytic fungi or combined with Trichoderma sp. were significantly deceased the disease severity (\%) and increased the plant growth parameters such as shoot length, shoot weight, root weight and number of pods. These results in accordance with those obtained by many workers (Elewa et al., 2011; Harman et al., 2004; Ribeiro et al., 2018; Terhonen et al., 2016). According to the available literature the mode of action of endophytic fungi may be due to or more from the following action: endophytic fungi are promising agents for biological control and may inhibit or reduce phytopathogen growth in several ways, including mycoparasitism, antibiosis, the production of metabolites, competition for nutrients, or resistance induction in plants. Several roles have been described to fungal endophytes, including providing protection against herbivorous insects, plant parasitic nematodes and plant pathogens (Breen, 1994). Fungal endophytes can reduce damage caused by pathogens in plants. Endophytes-induced defense responses against Fusarium wilt diseases have been reported for tomato, barley Asparagus sp. and bananas (Duijff et al., 1998; Fuchs et al., 1997). Mutualistic fungi may confer several benefits to plants such as tolerance to drought, metals disease, temperature and growth enhancement and nutrient acquisition. The endophytic fungus is having rich source of secondary metabolites which act as biological active agent in the higher plants. The natural 
compounds from the endophytes acts as growth inhibitor of plant pathogenic organism (Read 1999; Redman et al., 2002; Varma et al., 1999).

\section{References}

Abdallah, O. M., Hessen. Y. A and Abdel Magied Sozan (2015), "Economic study of production and consumption of potato in Egypt", Assiut Journal of Agriculture Sciences, Vol. 46 No. 1, pp. 58-67.

Abdel-Razik Sahar A., Sallam Nashwa M. A., Eraky Amal M. I. and Hassan M. H. A. (2012), "Integrated control of root rot and wilt disease of Faba bean by soil amendment with suppressive compost in combination with seed coating with an antagonistic yeast", Archives of Phytopathology and Plant Protection, Vol. 45 No. 14, pp. 1692-1707.

Abdou, E., Abd-Alla, H. M. and Galal, A. A. (2001), "Survey of sesame root rot/wilt disease in Minia and their possible control by ascorbic and salicylic acids", Assiut Journal of Agricultural Sciences, Vol. 32 No. 3, pp. 135-152.

Ahmed Hoda, A. M. (2008), Integrated control of sesame charcoal rot, Ph.D. Thesis, Faculty of Agriculture, Assiut University, Assiut, Egypt, pp. 100.
Al-Yemeni, M. N., Hussain, M. A. and Basahy, A. Y. (2000), "Mineral composition on of some sesame seeds grown in the Gizan area of Saudi Arabia", Phyton, Vol. 67, pp. 121-125.

Azevedo, J. L., Maccheroni, J. W., Pereira, J. O. and Araújo, W. L. (2000), "Endophytic microorganisms: a review on insect control and recent advances on tropical plants", Electronic Journal of Biotechnology, Vol. 3, pp. 40-65.

Bacon, C. W., Porter, J. K., Robbins, J. D. and Luttrell, E. S. (1977), "Epichloëty phina from toxic tall fescus grasses", Applied \& Environmental Microbiology, Vol. 34, pp. 576-581.

Breen, J. P. (1994), "Acremonium endophyte interactions with enhanced plant resistance to insects", Annual Review of Entomology, Vol. 39, pp. 401-423.

Carroll, G. (1988), "Fungal endophytes in stems and leaves: from latent pathogen to mutualistic symbiont", Ecology, Vol. 69, pp. 2-9.

Domsch, K. H., Gams, W. and Aderson, T. H. (2007), Compendium of soil fungi, $2^{\text {nd }}, \quad$ IHW-Velag, 85378 Eching, München, Bavaria, Germany, pp. 672.

Domsch, K. H., Gams, W. and Aderson, T. H. (1980), Compendium of soil fungi, Volume1, Academic Press, 
London, England, pp. 860.

Duijff, B. J., Pouhair, D., Olivain, C., Alabouvette, C. and Lemanceau, P. (1998), "Implication of systemic induced resistance in the suppression of Fusarium wilt of tomato by Pseudomonas flourescens WCS417r and by non-pathogenic Fusarium oxysporum Fo47", European Journal of Plant Pathology, Vol. 104, pp. 903-910.

Elewa, I. S., Sahab, A. F., Mostafa, M. H. and Ziedan, E. H. (2011), "Direct effect of biocontrol agents on wilt and root-rot diseases of sesame", Archives of Phytopathology and Plant Protection, Vol. 44 No. 5, pp. 493-504.

Ellis, M. B. (1971), Dematiaceaus hyphomycetes, Commonwealth Mycological Institute, Free Lane, Kew, Surrey, England, pp. 608.

Fuchs, J. G., Moenne-Loccoz, Y. and Defago, G. (1997), "Non-pathogenic Fusarium oxysporum strain Fo47 induced resistance to Fusarium wilt in tomato", Plant Disease, Vol. 81, pp. 492-496.

Garoe, N. T., Cabrera, R., Lisbel, B. R., Da Silva Evelyn, D. S., Cristina, G. I., Andreea, C. and Nélida, B. (2012), "Endophytic fungi from Vitis vinifera $\mathrm{L}$. isolated in Canary Islands and Azores as potential biocontrol agents of Botrytis cinerea Pers", Journal of Horticulture, Forestry and Biotechnology, Vol. 16 No. 1, pp. 1-6.

Ge, H. M., Shen, Y., Zhu, C. H., Tan, S. H., Ding, H., Song, Y. C. and Tan, R. X. (2008), "Penicidones A-C, three cytotoxic alkaloidal metabolites of an endophytic Penicillium sp.", Phytochemistry, Vol. 69, pp. 571-576.

Gomez, K. A. and Gomez, A. A. (1984), Statistical Procedures in Agricultural Research (2 $\left.{ }^{\text {ed }}\right)$, John Wiley and sons, New York, USA, pp. 680 .

Hallmann, J., Berg, G. and Schulz, B. (2007), "Isolation procedures for endophytic microorganisms", In: Schulz B., Boyle C. and Sieber T. eds, Microbial root endophytes, Springer Berlin Heidelberg, New York, USA, pp. 299-319.

Harman, G. E., Howell, C. R., Viterbo, A., Chet, I. and Lorito, M. (2004), "Trichoderma species-opportunistic, avirulent plant symbionts", Nature Reviews Microbiology, 2: 43-56.

Hassan, M. H. A. (1992), Biological control of certain plant diseases caused by Sclerotia producing fungi, Ph.D. Dissertation, Faculty of Agriculture, Assiut University, Assiut, Egypt, pp. 209.

Ismail, M. A., Abdel-Hafez, S. I. I., Hussein, N. A. and Abdel-Hameed, N. A. (2015), Contributions to the genus Fusarium in Egypt with dichotomous keys for identification 
of species, Tomasz M. Karpiński, Suchy Las, Poland, pp. 175.

John, F., Leslie, B. and Summerell, A. (2006), The Fusarium Laboratory Manual, Blackwell Publishing, Iowa, USA, pp. 388.

Kim, H. Y., Choi, G. J., Lee, H. B., Lee, S. W., Lim, H. K. and Jang, K. S. (2007), "Some fungal endophytes from vegetable crops and their antioomycete activities against tomato late blight", Letters in Applied Microbiology, Vo. 44, pp. 332-337.

Kotle, S. J. (1985), Diseases of Annual Oil Seed Crops: Volume II: Rapeseed-Mustard and sesame diseases, CRC Press Inc., Roca, Raton Florida, USA.

Nair, D .N. and Padmavathy, S. (2014), "Impact of endophytic microorganisms on plants, environment and humans", The Scientific World Journal, Vol. 2014 No. 250693, pp. 1-11.

Pitt, J. I. (1979), The genus Penicillium and its teleomorphic states Eupenicillium and Talaromyces, Academic Press Inc. Ltd., London, England, pp. 634.

Raper, K. B., and Fennell, D. I. (1965), The genus Aspergillus, Williams and Wilkins Co., Baltimore, USA, pp. 686.

Read, D.J. (1999,) "Mycorrhiza - The State of the Art", In: Varma A.,
Hock B. (eds), Mycorrhiza, Springer, Berlin, Heidelberg, Germany, pp. 3-34.

Redman, R. S., Roossinck, M. J., Maher, S., Andrews, Q. C., Schneider, W. L. and Rodriguez, R. J. (2002), "Field performance of cucurbit and tomato plants colonized with a nonpathogenic mutant of Colletotrichum magna (teleomorph: Glomerella magna; Jenkins and Winstead)", Symbiosis, Vol. 32, pp. 55-70.

Ribeiro, A. S., Polonio, J. C., Costa, A. T., Santos, C. M., Rhoden, S. A. and Azevedo, J. L. (2018), "Bioprospection of culturable endophytic fungi associated with the ornamental plant Pachystachys lutea", Current Microbiology, Vol. 75 No. 5, pp. 588-596.

Rukachaisirikul, V., Kaeobamrung, J., Panwiriyarat, W., Saitai, P., Sukpodma, Y., Phongpaichit, S. and Sakayaroj, J. (2007), "A new pyrone derivative from the entophytic fungus Penicillium paxilli PSUA71", Chemical and Pharmaceutical Bulletin, Vol. 55, pp. 1383-1384.

Sahab, A. F., Elewa, I. S., Mostafa, M. H. and Ziedan, E. H. (2008), "Morphological, physiological and pathological investigation on Fusarium oxysporum f. sp. sesame", Egyptian Journal of Agricultural Research, Vol. 1 No. 2, pp. 167181. 
Schulz, B., Boyle, C., Draeger, S., Römmert, A. K. and Krohn, K. (2002), "Endophytic fungi: a source of novel biologically active secondary metabolites", Mycological Research, Vol. 106, pp. 996-1004.

Terhonen, E., Sipari, N. and Asiegbu, F. O. (2016), "Inhibition of phytopathogens by fungal root endophytes of Norway spruce", Biological Control, Vol. 99 No. 8, pp. 53-63.

Varma, A., Verma, S., Sudha, Sahay, N., Butehorn, B. and Franken, P. (1999), "Piriformo sporaindica, a cultivable plant-growth-promoting root endophyte", Applied and Environmental Microbiology, Vol. 65, pp. 2741-2744.
Vidal, S., Jaber, L. R. (2015), "Entomopathogenic fungi as endophytes: Plant-endophyteherbivore interactions and prospects for use in biological control", Current Science, Vol. 108, pp. 4654.

Ziedan, E. H., Elewa, I. S., Mostafa, M. H. and Sahab, A. F. (2011), "Application of mycorrhizae for controlling root diseases of sesame", Journal of Plant Protection Research, Vol. 51 No, 4, pp. 355367. 